\title{
Differential gene expression profile in pig adipose tissue treated with/without clenbuterol
}

\author{
Jin Zhang1,2, Qiang He ${ }^{1}$, Qiu Y Liu ${ }^{1}$, Wei Guo ${ }^{1}$, Xue M Deng³, Wei W Zhang1, \\ Xiao X Hu*1 and Ning $\mathrm{Li}^{* 1}$
}

Address: ${ }^{1}$ State Key Laboratory for Agrobiotechnology, China Agricultural University, Beijing 100094, China, ${ }^{2}$ Life Science and Biotechnology Department, HeBei Normal University of Science \& Technology, Qinhuangdao, 066600, China and ${ }^{3}$ College of Animal Science and Technology, China Agricultural University, Beijing 100094, China

Email: Jin Zhang - zhangjin7688@163.com; Qiang He - siashq@sina.com; Qiu Y Liu - qiuyue1983921@163.com; Wei Guo - wguo2@wisc.edu; Xue M Deng - Deng@cau.edu.cn; Wei W Zhang - williamzhangww@gmail.com; Xiao X Hu* - huxx@cau.edu.cn;

Ning Li* - ninglbau@public3.bta.net.cn

* Corresponding authors

Published: 26 November 2007

BMC Genomics 2007, 8:433 doi:10.1/86/147|-2164-8-433
Received: 8 February 2007

Accepted: 26 November 2007

This article is available from: http://www.biomedcentral.com//47/-2/64/8/433

(c) 2007 Zhang et al; licensee BioMed Central Ltd.

This is an Open Access article distributed under the terms of the Creative Commons Attribution License (http://creativecommons.org/licenses/by/2.0), which permits unrestricted use, distribution, and reproduction in any medium, provided the original work is properly cited.

\begin{abstract}
Background: Clenbuterol, a beta-agonist, can dramatically reduce pig adipose accumulation at high dosages. However, it has been banned in pig production because people who eat pig products treated with clenbuterol can be poisoned by the clenbuterol residues. To understand the molecular mechanism for this fat reduction, cDNA microarray, real-time PCR, two-dimensional electrophoresis and mass spectra were used to study the differential gene expression profiles of pig adipose tissues treated with/without clenbuterol. The objective of this research is to identify novel genes and physiological pathways that potentially facilitate clenbuterol induced reduction of adipose accumulation.

Results: Clenbuterol was found to improve the lean meat percentage about 10 percent $(P<0.05)$. The adipose cells became smaller and the muscle fibers became thicker with the administration of clenbuterol. The mRNA abundance levels of 82 genes (ESTs) were found to be statistically differentially expressed based on the Student t-test $(P<0.05)$ in the microarray analyses which contained 3358 genes (ESTs). These 82 genes (ESTs) were divided into four groups according to their Gene Ontology Biological Process descriptions. 16 genes were cellular metabolism related genes (including five related to lipid metabolism such as apolipoprotein D and apolipoprotein R), 10 were signal transduction related genes, 45 were expressed sequence tags (ESTs) and II others were of various categories. Eleven of the 82 genes (ESTs) were chosen for real-time PCR analysis, with eight genes showing similar induction magnitude as that seen in the microarray data. Apolipoprotein $\mathrm{R}$ was also found to be up-regulated by the proteomic analysis.

Conclusion: Pig fat accumulation was reduced dramatically with clenbuterol treatment. Histological sections and global evaluation of gene expression after administration of clenbuterol in pigs identified profound changes in adipose cells. With clenbuterol stimulation, adipose cell volumes decreased and their gene expression profile changed, which indicate some metabolism processes have been also altered. Although the biological functions of the differentially expressed genes are not completely known, higher expressions of these molecules in adipose tissue might contribute to the reduction of fat accumulation. Among these genes, five lipid metabolism related genes were of special interest for further study, including apoD and apoR. The apoR expression was increased at both the RNA and protein levels. The apoR may be one of the critical molecules through which clenbuterol reduces fat accumulation.
\end{abstract}




\section{Background}

The $\beta_{2}$-agonist clenbuterol $(0.8-3.2 \mu \mathrm{g} / \mathrm{kg}$ body weight twice daily) is used as a bronchodilator for the treatment of asthma in humans and as a bronchodilator as well as a tocolytic agent in veterinary medicine [1]. In the past decade, high dosages of clenbuterol (ten to one hundred times the clinically active dose) have been fed to livestock to improve feed conversion, reduce body fat and increase muscle mass [2,3]. However, people who eat the animal products can be poisoned by the clenbuterol residues [46]. Therefore, the use of clenbuterol for growth promotion in food-producing animals is not approved within China, the European community, the United States, and most other countries $[2,7]$.

Clenbuterol influences cell metabolism by combining with $\beta_{2}$-adrenergic receptors and by increasing the cAMP concentration in cells. In adipocytes, stimulation of $\beta$ adrenergic receptors (by hormones) increases cyclic AMP levels and activates protein kinase A (PKA), which stimulates lipolysis by phosphorylating hormone-sensitive lipase and perilipin [8-11]. However the molecular level mechanism by which clenbuterol influences adipose accumulation is still not understood.

Recently, global gene/protein expression analysis techniques using DNA microarray/2-D gel analyses have been widely used to define the characteristics and specific patterns of gene expressions elicited by various toxicants [1214]. In this study, the molecular level mechanism by which clenbuterol reduces fat accumulation was studied with cDNA microarray and proteomics techniques to analyze the fat tissue of Chinese miniature pigs treated with/ without clenbuterol.

\section{Results}

Adipose accumulation decreased dramatically by clenbuterol administration

HPLC analyses of blood samples showed that the clenbuterol concentrations in the test pigs fed with clenbuterol were about $20 \mathrm{ng} / \mathrm{ml}$ in the 3 month-old pigs and about $100 \mathrm{ng} / \mathrm{ml}$ in the 4 month-old pigs. Clenbuterol could not be detected in the control pigs fed without clenbuterol (Additional file 1 Table S1). The test pigs and control pigs did not exhibit different weights (Additional file 1 Table S2), but did exhibit different body compositions (Table 1). The effect of clenbuterol on body composition became more dramatic with advancing age. In the 3 month-old group, the lean meat percentage was increased by $2 \%$, the back fat thickness was reduced by $\sim 0.2 \mathrm{~cm}$, and the loin muscle area was reduced by $4.7 \mathrm{~cm}^{2}$. This difference was statistically significant $(P<0.05)$. In the 4 month-old group, the lean meat percentage was increased by $10.99 \%$, the back fat thickness was reduced by $0.38 \mathrm{~cm}$ and the loin muscle area was reduced by $2.18 \mathrm{~cm}^{2}$. The changes of the lean meat percentage and the loin muscle area were strongly statistically significant $(P<0.01)$ while the changes of the back fat thickness were statistically significant $(\mathrm{P}<0.05)$. These data indicate that clenbuterol plays a role in pig adipose reduction. The sample quality was sufficient for further analysis to identify molecules with changed expression levels and molecules which impact adipose accumulation.

\section{Muscle fibers became thicker and adipose cells became smaller with the administration of clenbuterol}

Clenbuterol produces specific protein anabolic effects in skeletal muscle in addition to lipolysis in adipose tissue of various vertebrates [15-18]. However, there has not yet been any research explaining how these two types of tissues are changed by the administration of clenbuterol. Muscle and adipose histological sections were analyzed to understand how these two tissue types are changed (Figure $1 \mathrm{~A} \& 1 \mathrm{~B})$.

Paraffin histological section analyses were done using samples from the 4 month-old pig's biceps femoris. Four histological section slides were prepared for each pig, two transverse muscle fiber slides and two longitudinal muscle fiber slides, for analysis of the cross-sectional area of the fibers with a TD2000 real-color pathology image analysis system (Beijing Tiandibainian Scientific Company, Ltd.). The cross-sectional areas of the muscle fibers of the test pigs and the control pigs were significantly different

Table I: Body composition of pigs treated with/without clenbuterol

\begin{tabular}{|c|c|c|c|c|c|c|c|c|}
\hline Age & \multicolumn{2}{|c|}{3 month-old } & \multicolumn{2}{|c|}{3 month-old } & \multicolumn{2}{|c|}{4 month-old } & \multicolumn{2}{|c|}{4 month-old } \\
\hline Clenbuterol dosage* & \multicolumn{2}{|c|}{0} & \multicolumn{2}{|c|}{25} & \multicolumn{2}{|c|}{0} & \multicolumn{2}{|c|}{50} \\
\hline Pig & $\operatorname{Hog} 2$ & Sow 2 & Hog I & Sow 1 & $\operatorname{Hog} 4$ & Sow 4 & $\operatorname{Hog} 3$ & Sow 3 \\
\hline Lean meat percentage of carcass (\%) & 52.34 & 52.46 & 55.09 & 55.39 & 41.38 & 41.52 & 52.36 & 52.52 \\
\hline Thickness of back fat $(\mathrm{cm})$ & 2.361 & 2.311 & 2.132 & 2.104 & 3.229 & 3.171 & 2.824 & 2.812 \\
\hline Loin muscle area $\left(\mathrm{cm}^{2}\right)$ & 19.460 & 19.516 & 24.086 & 24.312 & 23.063 & 23.103 & 25.228 & 25.312 \\
\hline
\end{tabular}

*twice daily with the unit of ( $\mathrm{mg} / \mathrm{kg}$ body weight)

The carcass lean meat percentage, the back fat thickness and the loin muscle area were all changed statistically in both the 3 month-old group and the 4 month-old group after clenbuterol treatment $(P<.05)$. 
A

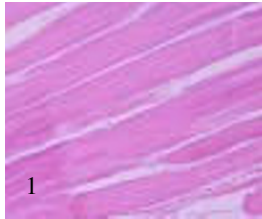

$10 \times 20$

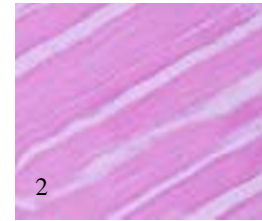

$10 \times 20$

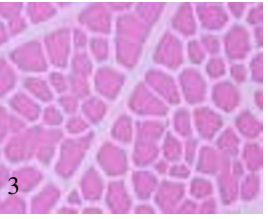

$10 \times 40$

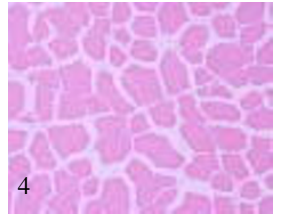

$10 \times 40$

B

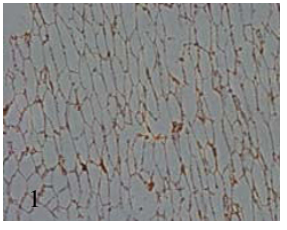

$10 \times 10$

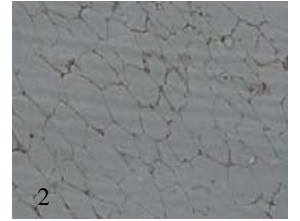

$10 \times 10$

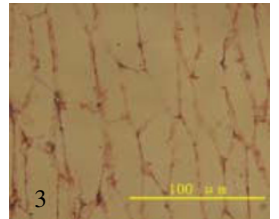

$10 \times 40$

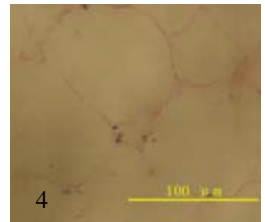

$10 \times 40$

\section{Figure I}

I A. Skeleton muscle (biceps femoris) histological section of pigs with/without the administration of clenbuterol. I. transverse, test pigs. 2. transverse, control pigs. 3. longitudinal, test pigs. 4. longitudinal, control pigs. Vertical fiber sections analyzed with TD2000 real-color pathology image analysis system (Beijing Tiandibainian Scientific Company Ltd.). The muscle fibers of pigs become thicker when treated with clenbuterol. I B. Subcutaneous back fat (at the fifth lumbar vertebra level) histological section of pigs with/without the administration of clenbuterol. I. amplified I $0 \times 10$ of test pigs. 2. amplified $10 \times 10$ of control pigs. 3. amplified $10 \times 40$ of test pigs. 4 . amplified $10 \times 40$ of control pigs. The sizes of the pig adipose cells decreased when treated with clenbuterol. The cell size was analyzed by counting cells on the slide visible through the microscope eyepiece.

with a student t-test $P$ value of 0.0224 (Additional file 1 Table S3). The results show that the administration of clenbuterol increased the muscle fiber thicknesses in the pigs.

The 4 month-old pig's back fat tissue (at the fifth lumbar vertebra level) was also analyzed using paraffin histological section. Five random areas on the slides were chosen for the adipose cell size analyses. The cell sizes were analyzed by counting all the cells on the slides visible through the microscope eyepiece at the $10 \times 40$ magnification (Additional file 1 Table S4). Numbers of cells in the test group were strongly statistically more than in the control group $(\mathrm{P}<0.01)$. Thus, clenbuterol caused a reduction in adipocyte size.

The clenbuterol thickened the pig muscle fibers and reduced the sizes of the pig adipocyte cells in the back fat tissues. Clenbuterol is known to increase muscle mass and reduce body fat. We suggest that clenbuterol increases the muscle mass by thickening the muscle fibers and reduces the body fat by shrinking the adipose cells. The size of the adipose cells depends on the sizes of the lipid droplets in the cells. Therefore, the adipose cells become smaller as the clenbuterol reduces the lipid droplets in the adipose cells.

\section{cDNA microarray identified 82 genes with changed mRNA abundance in adipose tissue with stimulation by clenbuterol}

Eight microarray slides were used (four for the 3 monthold group and four for the 4 month-old group) for global evaluation of the gene expression in the adipose tissue after administration of clenbuterol. 8335 spots representing 2770 genes (ESTs) in the 3 month-old group and 8740 spots representing 2862 genes (ESTs) in the 4 month-old group passed the spots quality filter and were analyzed with the Student $\mathrm{t}$ test. 507 genes in the 3 month-old 
group ( $\mathrm{P}<0.05$ in four microarray slides) and 336 genes in the 4 month-old group $(\mathrm{P}<0.05$ in four microarray slides) were differentially expressed (data not shown). The goal of this study was to identify gene expression profiles affected by clenbuterol. Therefore, genes that were differentially expressed in both groups ( 82 genes in total) were selected for further study as being differentially expressed in adipose tissue with stimulation by clenbuterol (Fig. 2).

These 82 genes (ESTs) were divided into 4 groups according to their Gene Ontology Biological Process descriptions. 16 genes were cellular metabolism related genes (Table 2), 10 were signal transduction related genes (Table 3), 45 were expressed sequence tags (ESTs) (Table 4) (no homologous sequences were found in the NCBI nucleotide database for 17 ESTs, while the other 28 ESTs hit only some EST sequences without any functional annotations) and the other 11 genes were of various categories (Table 5). 45 EST sequences were deposited at dbEST of NCBI [19].

73\% cDNA microarray results confirmed by real-time PCR Seven differentially expressed genes (positive genes) were chosen for real-time PCR analysis with the 4 month-old group samples used to validate the microarray data (Table 6). Clone rpfat_18309 and rpfat_19990 representing proalpha- 1 type 3 collagen were not detected by the real-time PCR. The other five clones, for genes of apoD (apolipoprotein D), PRKAR1A (CAMP dependent protein kinase

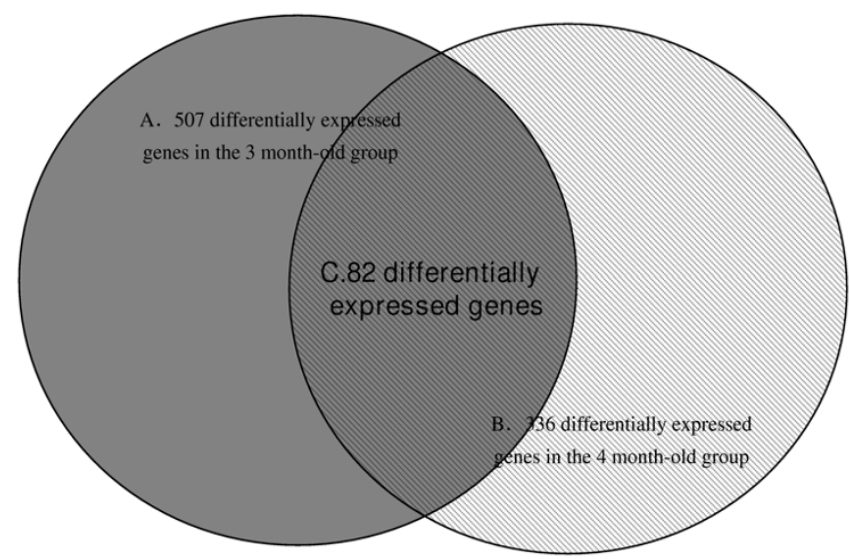

Figure 2

82 genes were differentially expressed in the DNA microarray analysis in pig fat tissue with clenbuterol administration $(P<.05)$ in both groups. $A$. The black circle indicates the 507 differentially expressed genes in the 3 month-old group ( $P<.05$ in four microarray slides). $B$. The cross-hatched circle indicates the 336 differentially expressed genes in the 4 month-old group $(P<.05$ in four microarray slides). C. The overlapping region indicates the 82 differentially expressed genes in both the 3 month old group and the 4 month old group that were of interest. type I regulatory), COL1A2 (pro-alpha-2 chain of type I procollagen) and COL1A1 (prepro-alpha1(I) collagen), showed a statistically significant increase in mRNA abundance with administration of clenbuterol $(P<0.05)$.

The SCD (stearoyl-CoA desaturase) and HSL (hormonesensitive lipase) genes are very important in lipid metabolism. The mRNA abundance of stearoyl-CoA desaturase (SCD) decreased in the 3 month-old group and increased in the 4 month-old group, while HSL was not significantly differentially expressed by stimulation with clenbuterol in the microarray analysis. PMP22 (peripheral myelin protein 22) and PHPT1 (phosphohistidine phosphatase 1) were also not significantly differentially expressed by stimulation with clenbuterol in the microarray analysis. These four genes (negative genes) were not significantly differentially expressed by the real-time PCR analysis with 8 pig samples $(\mathrm{P}>0.05)$ (Table 7$)$. In total, 11 genes were analyzed by the real-time PCR. Eight genes showed similar induction magnitude as that seen in the microarray data; two could not be detected, and one was inconsistent with the microarray results. Thus, these results provide strong biological validation of the results from the microarray experiment.

\section{Apolipoprotein $R$ protein highly presented in adipose with the administration of clenbuterol}

After spot detection, background subtraction and volume normalization, $600 \pm 50$ protein spots were detected in adipose cells using two-dimensional electrophoresis methods. Two spots found to be only expressed in the test group were chosen for digestion in-gel for peptide mass fingerprint (PMF) analysis with a mass spectrograph (Fig. 3A \&3B). A Mascot search using the PMF data matched seven of the peptides with peptides from apolipoprotein $R$, with a sequence coverage of $36 \%$ and an expectation of 0.00043 [20]. The other differentially expressed protein did not give any positive results in the database search.

\section{Discussion}

To identify the genes responding to clenbuterol treatment in adipose tissue, a cDNA microarray, real-time PCR and 2-dimensional protein gel analysis were used. 82 genes were identified as being differentially expressed by the microarray analysis with student test $(\mathrm{p}<0.05)$. These were categorized into to four groups.

\section{Lipid metabolism related genes in group I}

16 differentially expressed genes are involved in cellular metabolism (Table 2). Five of them, including apoD (apolipoproteinD), apoR (apolipoprotein R), HAD (L-3hydroxyacyl-CoA dehydrogenase precursor), PAP type $2 \mathrm{~A}$ isoform 1 (phosphatidic acid phosphatase type 2A isoform 1) and SCD (stearoyl-CoA desaturase), directly participate in lipid metabolism. 
Table 2: Group I of differentially expressed genes: Cell metabolism

\begin{tabular}{|c|c|c|c|c|}
\hline \multirow{2}{*}{$\begin{array}{c}\begin{array}{c}\text { GenBank Access No. } \\
\text { (Clone No. on Microarray) }\end{array} \\
\text { NM 001647 (rpfat_18926) }\end{array}$} & \multirow{2}{*}{$\begin{array}{l}\text { Gene name } \\
\text { Apolipprotein D (ApoD) }\end{array}$} & \multirow{2}{*}{$\begin{array}{l}\text { Annotation* } \\
\text { Lipid metabolism }\end{array}$} & \multicolumn{2}{|c|}{$\begin{array}{l}\text { Induction Fold change } \\
3 \text { month \& } 4 \text { month }\end{array}$} \\
\hline & & & 1.76 & 1.67 \\
\hline L06820(rpfat_18262) & Apolipprotein R (ApoR) & Lipid metabolism & 2.58 & 1.80 \\
\hline XM 854434.I(rpig_3250) & $\begin{array}{l}\text { Canis familiaris similar to phosphatidic acid } \\
\text { phosphatase type } 2 \mathrm{~A} \text { isoform } \mathrm{I} \text {, transcript variant } 2\end{array}$ & Lipid metabolism & 1.27 & 1.14 \\
\hline NM 006022 (rpigfat_10082) & $\begin{array}{l}\text { transforming growth factor beta-stimulated } \\
\text { protein }\end{array}$ & $\begin{array}{l}\text { modulates the frequency, rate } \\
\text { or extent of DNA-dependent } \\
\text { transcription }\end{array}$ & 1.25 & 1.13 \\
\hline NM 007I58 (rpfat_I83I7) & NRAS-related gene (DISI55E) & & 1.25 & 1.54 \\
\hline NM 014828 (rpfat_I6693) & KIAA0737 gene product (KIAA0737) & & 1.28 & 1.43 \\
\hline NM_003069(rpfat_18518) & $\begin{array}{l}\text { SWI/SNF related, matrix associated, actin } \\
\text { dependent regulator of chromatin, subfamily a, } \\
\text { member I (SMARCAI) }\end{array}$ & & 1.23 & 1.64 \\
\hline NM 000985 (rpfat_19876) & ribosomal protein LI7 (RPLI7), mRNA & protein translation & 1.47 & 1.09 \\
\hline LOC484530(rpfat_I5686) & ribosomal protein SIO & protein translation & 1.33 & 1.15 \\
\hline M64620 (rpfat_4I79) & cathepsin B & lysosomal cysteine proteinase & 1.14 & 1.13 \\
\hline DQ673096(rpfat_1977I) & $\begin{array}{l}\text { Eukaryotic translation elongation factor I alpha } \\
\text { (EEFIA) }\end{array}$ & protein translation & 1.70 & 1.29 \\
\hline X81197(rpfat_13772) & archain I & $\begin{array}{l}\text { endoplasmic reticulum to Golgi } \\
\text { transport }\end{array}$ & 2.15 & 1.62 \\
\hline AF027652 (rpfat_19670) & $\begin{array}{l}\text { L-3-hydroxyacyl-CoA dehydrogenase precursor } \\
\text { (HAD) mRNA, }\end{array}$ & Lipid metabolism & -1.30 & 1.11 \\
\hline AY487830 (rpfat_17395) & $\begin{array}{l}\text { Sus scrofa stearoyl-CoA desaturase (SCD) gene, } \\
\text { exons I through } 6 \text { and complete cds }\end{array}$ & Lipid metabolism & -1.89 & 1.03 \\
\hline DQ629164 (rpfat_4193) & ribosomal protein $\mathrm{LIOa}$ & protein translation & -1.01 & 1.03 \\
\hline NP 001001636 (rpfat_18915) & ribosomal protein L32 & Protein translation & -1.79 & -1.01 \\
\hline
\end{tabular}

*according to description of the Gene Ontology Biological Process Category

*All the genes in the table were differentially expressed according to the student $t$ test in the eight microarray slides $(P<.05)$

Table 3: Group II of differentially expressed genes: Signal transduction*

\begin{tabular}{|c|c|c|c|c|}
\hline \multirow{2}{*}{$\begin{array}{c}\begin{array}{c}\text { GenBank Access No. } \\
\text { (Clone No. on Microarray) }\end{array} \\
\underline{\text { X05942 (rpfat_I766I) }}\end{array}$} & \multirow{2}{*}{$\begin{array}{c}\text { Gene name } \\
\\
\text { cAMP dependent protein } \\
\text { kinase type I regulatory } \\
\text { (PRKARIA) }\end{array}$} & \multirow{2}{*}{$\begin{array}{c}\text { Annotation } \\
\text { causes the dissociation of the inactive } \\
\text { holoenzyme }\end{array}$} & \multicolumn{2}{|c|}{$\begin{array}{l}\text { Induction Fold change } 3 \\
\text { month \& } 4 \text { month }\end{array}$} \\
\hline & & & 2.0 & 2.0 \\
\hline$\underline{\text { Z33879 (rpfat_I7754) }}$ & $\begin{array}{l}\text { mRNA encoding G-beta like } \\
\text { protein (RACKI) }\end{array}$ & $\begin{array}{l}\text { a physiological mediator of agonist-induced } \\
\qquad \mathrm{Ca}^{2+} \text { release }\end{array}$ & 1.29 & 1.05 \\
\hline NM 204675.I (rpfat_I7793) & $\begin{array}{c}\text { wingless-type MMTV } \\
\text { integration site family, member } \\
\text { 3A (WNT3A) }\end{array}$ & $\begin{array}{l}\text { leads to an increase in intracellular calcium and } \\
\text { activation of protein kinase } C(P K C)\end{array}$ & 1.27 & 1.09 \\
\hline$\underline{\text { U57092 (rpfat_19360) }}$ & RAB30 & member of the RAS oncogene family & 2.05 & 2.41 \\
\hline$\underline{\text { U0529I (rpfat_10974) }}$ & fibromodulin & $\begin{array}{c}\text { participate in the assembly of the extracellular } \\
\text { matrix as it interacts with type I and type II } \\
\text { collagen fibrils }\end{array}$ & 1.28 & 1.04 \\
\hline MI898I (rpfat_8258) & $\begin{array}{l}\text { SI00 calcium binding protein } \\
\text { A6 }\end{array}$ & $\begin{array}{l}\text { helps stimulation } \mathrm{Ca}^{2+} \text {-dependent insulin } \\
\text { release, prolactin secretion and exocytosis }\end{array}$ & 5.96 & 1.61 \\
\hline 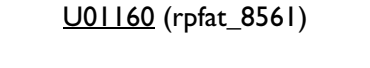 & $\begin{array}{c}\text { transmembrane } 4 \text { superfamily } \\
\text { protein (SAS) }\end{array}$ & growth-related cellular processes & 1.09 & 1.21 \\
\hline$\underline{\text { AF268463 }}$ (rpfat_I5672) & $\begin{array}{l}\text { voltage-dependent anion } \\
\text { channel } 3 \text { (VDAC3) }\end{array}$ & Calcium signaling pathway & -1.26 & -1.05 \\
\hline NM 003248 (rpigfat_10263) & thrombospondin 4 (THBS4) & $\begin{array}{l}\text { forms a pentamer and can bind to heparin and } \\
\text { calcium }\end{array}$ & -1.04 & I.II \\
\hline BC024040 (rpfat_18349) & $\begin{array}{l}\text { Homo sapiens CXXC finger } 5 \\
\text { mRNA }\end{array}$ & $\begin{array}{l}\text { up-regulation of I-kappaB kinase/NF-kappaB } \\
\text { cascade }\end{array}$ & -1.41 & 1.04 \\
\hline
\end{tabular}

*according to description of the Gene Ontology Biological Process Category

*All the genes in the table were differentially expressed according to the student $t$ test in the eight microarray slides $(P<.05)$ 
Table 4: Group III of differentially expressed genes: Expressed Sequence Tags (ESTs)

\begin{tabular}{|c|c|c|c|}
\hline \multirow[t]{2}{*}{ GenBank Access No. } & \multirow[t]{2}{*}{ Clone No. on Microarray } & \multicolumn{2}{|c|}{ Induction Fold change } \\
\hline & & 3 month & 4 month \\
\hline ES605520 & rpfat_907I & 1.05 & 1.06 \\
\hline ES605522 & rpig_38II & 1.63 & 1.42 \\
\hline ES605503 & rpfat_19982 & 1.41 & 1.27 \\
\hline ES605504 & rpig_3786 & 1.01 & 1.10 \\
\hline ES605505 & rpfat_II284 & 1.21 & 1.21 \\
\hline ES605524 & rpfat_I7910 & 1.55 & 1.05 \\
\hline ES605516 & rpfat_I536I & 1.58 & 1.25 \\
\hline ES605525 & rpfat_15914 & 1.38 & 1.13 \\
\hline ES605526 & rpfat_16368 & 1.55 & 1.12 \\
\hline ES605506 & rpfat_I846I & 1.33 & 1.07 \\
\hline ES605507 & rpfat_II050 & 1.41 & 1.17 \\
\hline ES605508 & rpigfat_10350 & 1.84 & 1.21 \\
\hline ES605509 & rpigfat_1025I & 1.36 & 1.21 \\
\hline ES605510 & rpig_3845 & 1.06 & 1.09 \\
\hline ES6055II & rpfat_9552 & 1.05 & 1.08 \\
\hline ES605528 & rpfat_19923 & 1.24 & 1.08 \\
\hline ES605530 & rpfat_I6045 & 1.36 & 1.18 \\
\hline$\overline{E S 605532}$ & rpigfat_10253 & 1.77 & 1.26 \\
\hline ES605533 & rpig_4030 & 1.07 & 1.11 \\
\hline ES605535 & rpfat_13525 & 1.49 & 1.14 \\
\hline ES605536 & rpfat_5467 & 1.79 & 1.58 \\
\hline ES605537 & rpfat_I8469 & 1.18 & 1.14 \\
\hline ES605538 & rpfat_9125 & 1.34 & 1.24 \\
\hline ES605539 & rpfat_847I & 2.32 & 1.37 \\
\hline ES605540 & rpfat_I7820 & 1.39 & 1.13 \\
\hline ES6055I3 & rpfat_16623 & 1.54 & 1.22 \\
\hline ES60554I & rpfat_I 7845 & 1.21 & 1.38 \\
\hline ES605543 & rpigfat_10285 & $\mathrm{I} .40$ & 1.08 \\
\hline$\overline{E S 605514}$ & rpfat_|84II & 1.97 & 1.57 \\
\hline ES605544 & rpfat_12523 & 1.52 & 1.33 \\
\hline ES605518 & rpig_3750 & 1.60 & 1.43 \\
\hline ES6055I5 & rpfat_|708I & 1.57 & 1.14 \\
\hline ES605519 & rpfat_10949 & 1.08 & 1.16 \\
\hline ES65231I & rpfat_II494 & 1.05 & 1.21 \\
\hline$\overline{\mathrm{ES} 652312}$ & rpfat_II443 & 1.09 & 1.46 \\
\hline ES652313 & rpfat_I8636 & 1.83 & 1.22 \\
\hline ES605523 & rpigfat_9891 & -1.28 & 1.04 \\
\hline ES605512 & rpfat_19175 & -2 & 1.00 \\
\hline ES605527 & rpfat_I 8872 & -1.28 & 1.03 \\
\hline$\overline{E S 605529}$ & rpfat_10950 & -1.59 & 1.02 \\
\hline ES605534 & rpig_3746 & -1.03 & 1.10 \\
\hline ES605531 & rpfat_II274 & -1.35 & 1.01 \\
\hline ES605517 & rpfat_12459 & -1.10 & 1.08 \\
\hline ES605542 & rpfat_I5623 & $-|.5|$ & 1.13 \\
\hline ES605521 & rpfat_II483 & -1.42 & -1.06 \\
\hline
\end{tabular}

*All the genes in the table were differentially expressed according to the student $t$ test in the eight microarray slides $(P<.05)$

Both apoD and apoR were up-regulated by the administration of clenbuterol. ApoD is a component of high density lipoproteins [21]. ApoR is a 23-kDa protein found on very low-density lipoproteins (VLDL), on chylomicrons, and in the $\mathrm{d}>1.21 \mathrm{~g} / \mathrm{ml}$ fraction of pig plasma [22]. ApoR was also found to be up-regulated by proteomic analysis. Although the physiologic functions of apoD and apoR in adipose tissue are unknown, they may respond to clenbuterol stimulation to alter lipid metabolism.

Type 2 PAPs appear to metabolize a wide range of lipid mediators derived from both glycero- and sphingolipids $[23,24]$. SCD is the enzyme responsible for conversion of saturated fatty acids into monounsaturated fatty acids 
Table 5: Group IV of differentially expressed genes: Various categories*

\begin{tabular}{|c|c|c|c|c|}
\hline \multirow{2}{*}{$\begin{array}{c}\begin{array}{c}\text { GenBank Access No. } \\
\text { (Clone No. on Microarray) }\end{array} \\
\text { AF246221 (rpfat_12517) }\end{array}$} & \multirow{2}{*}{$\begin{array}{l}\text { Gene name } \\
\text { transmembrane protein BRI }\end{array}$} & \multirow{2}{*}{$\begin{array}{c}\text { Annotation } \\
\text { developmental processes }\end{array}$} & \multicolumn{2}{|c|}{$\begin{array}{l}\text { Change test/control } 3 \\
\text { month \& } 4 \text { month }\end{array}$} \\
\hline & & & 1.27 & 1.13 \\
\hline AFI78980 (rpigfat_9892) & D-prohibitin mRNA & developmental processes & 1.54 & 1.24 \\
\hline NM 000089 (rpfat_|26|2) & collagen, type I, alpha 2 (COLIA2) & developmental processes & 2.48 & 1.53 \\
\hline Z74616 (rpfat_16033) & $\begin{array}{l}\text { mRNA encoding Pro-alpha-2 chain of type I } \\
\text { procollagen (COLIA2) }\end{array}$ & cell structure and mobility & 4.20 & 2.52 \\
\hline$\underline{\mathrm{AB033007}}$ (rpfat_I5395) & mRNA for KIAAII8I protein & cellular localization & 1.29 & 1.08 \\
\hline$\underline{X 06700}$ (rpfat_18309) & $\begin{array}{l}\text { mRNA 3' region for pro-alphal (III) } \\
\text { collagen(COL3AI) }\end{array}$ & cell structure and mobility & 3.16 & 4 \\
\hline$\underline{Z 746 I 5}$ (rpfat_8523) & $\begin{array}{l}\text { mRNA for prepro-alphal (I) collagen } \\
\text { (COLIAI) }\end{array}$ & cell structure and mobility & 2.86 & 2.86 \\
\hline$\underline{X 14420}$ (rpfat_19990) & $\begin{array}{l}\text { mRNA for pro-alpha-I type } 3 \text { collagen } \\
\text { (COL3AI) }\end{array}$ & cell structure and mobility & 3.29 & 3.33 \\
\hline BC093076 (rpigfat_10250) & $\begin{array}{l}\text { Homo sapiens peptidylprolyl isomerase A } \\
\text { (cyclophilin A) }\end{array}$ & protein folding and stabilization & 1.28 & 1.05 \\
\hline NM_006136 (rpfat_18939) & $\begin{array}{l}\text { capping protein (actin filament) muscle Z-line, } \\
\text { alpha }\end{array}$ & cell mobility & 2.02 & 1.61 \\
\hline NM 005915 (rpfat_I5643) & $\begin{array}{l}\text { minichromosome maintenance deficient (mis5, } \\
\text { S. pombe) } 6\end{array}$ & cell cycle & 1.75 & 1.62 \\
\hline
\end{tabular}

*according to description of the Gene Ontology Biological Process Category

*All the genes in the table were differentially expressed according to the student $t$ test in the eight microarray slides $(P<.05)$.

(MUFA) in mammalian adipocytes [25]. HAD is a mitochondrial protein that catalyzes the oxidation of a wide variety of fatty acids, alcohols, and steroids $[26,27]$.

The identification of these molecules is not sufficient to draw out the clenbuterol physiological pathway. However, with the study of the ESTs in Table 4, some new functional genes related to lipid metabolism will be identified. The mechanism of clenbuterol reducing fat accumulation will be revealed on the molecular level based on these differentially expressed genes.

\section{Other cellular metabolism related genes in group $I$}

Of the other cellular metabolism related genes, EEF1A (eukaryotic translation elongation factor 1 alpha) is responsible for the enzymatic delivery of aminoacyl
tRNAs to the ribosome. EEF1A up-regulation indicates that translation activity in adipose cells is enhanced by clenbuterol stimulation. Aarchain 1 may be involved in vesicle structure or trafficking [28] and its up regulation suggests that transport of cargos from the endoplasmic reticulum (ER) to the Golgi was enhanced. Cathepsin B is a lysosomal cysteine proteinase composed of a dimer with disulfide-linked heavy and light chains. D1S155E (NRASrelated gene), SMARCA1 (SWI/SNF related, matrix associated, actin dependent regulator of chromatin, subfamily a, member 1) and KIAA0737 (KIAA0737 gene product) modulate the frequency, rate or extent of DNA-dependent transcription.

Together, these findings indicate that some metabolic processes, such as DNA transcription, protein translation

Table 6: Real-time PCR validation of microarray positive results

\begin{tabular}{lllll}
\hline \multirow{2}{*}{$\begin{array}{c}\text { Gene* } \\
\text { (Clone No. on Microarray) }\end{array}$} & \multicolumn{3}{c}{ Hog 3/hog 4} & Sow 3/sow 4 \\
\cline { 2 - 5 } & \multicolumn{1}{c}{ Change (test/control) } & & P value & Change (test/control) \\
\hline ApoD (rpfat_I8926) & 12.28 & 0.013 & 7.49 & 0.002 \\
PRKARIA(rpfat_1766I) & 6.65 & 0.014 & 8.18 & 0.046 \\
COLIAI (rpfat_8523) & 20.08 & 0.00008 & 13.47 & 0.00001 \\
COLIA2 (rpfat_16033) & 2.87 & 0.0010 & 0.0078 \\
COLIA2 (rpfat_17393) & 3.00 & 0.0002 & 3.66 & 0.0002 \\
COL3AI(rpfat_18309) & Not detected & Not detected & Not detected & Not detected \\
COL3AI (rpfat_1999) & Not detected & Not detected & Not detected & Not detected
\end{tabular}

* The full names of each gene are listed in Tables 2-5.

Five of the seven genes were confirmed by real-time PCR. 
Table 7: Real-time PCR validation of microarray negative results

\begin{tabular}{|c|c|c|c|c|c|c|c|c|}
\hline \multirow{2}{*}{$\begin{array}{c}\text { Gene* (Clone No. } \\
\text { on Microarray) }\end{array}$} & \multicolumn{2}{|c|}{ Hog I/hog 2} & \multicolumn{2}{|c|}{ Sow $1 /$ sow 2} & \multicolumn{2}{|c|}{ Hog 3/hog 4} & \multicolumn{2}{|c|}{ Sow 3/sow 4} \\
\hline & $\begin{array}{c}\text { Change } \\
\text { (test/control) }\end{array}$ & $P$ value & $\begin{array}{c}\text { Change } \\
\text { (test/control) }\end{array}$ & $P$ value & $\begin{array}{c}\text { Change } \\
\text { (test/control) }\end{array}$ & $P$ value & $\begin{array}{c}\text { Change } \\
\text { (test/control) }\end{array}$ & $P$ value \\
\hline SCD (rpfat_I6685) & 1.56 & 0.1680 & 0.77 & 0.2119 & 1.49 & 0.0822 & 1.23 & 0.9943 \\
\hline HSL (rpfat_II096) & 1.29 & 0.0679 & 1.11 & 0.2989 & 1.29 & 0.3462 & 1.06 & 0.5294 \\
\hline $\begin{array}{c}\text { PMP22a } \\
\text { (rpfat_18575) }\end{array}$ & 1.15 & 0.6198 & 1.16 & 0.3178 & 1.24 & 0.6900 & $\mathrm{I} .46$ & 0.1175 \\
\hline $\begin{array}{c}\text { PHPTIb } \\
\text { (rpfat_I53।2) }\end{array}$ & 0.75 & 0.1218 & 0.95 & 0.5811 & 1.24 & 0.4694 & 1.46 & 0.4869 \\
\hline
\end{tabular}

* The full names of each gene are listed in Tables 2-5.

a : PMP22: peripheral myelin protein 22

b :PHPTI: Phosphohistidine phosphatase I

Three genes (HSL, PMP22 and PHPTI) were confirmed by real-time PCR.
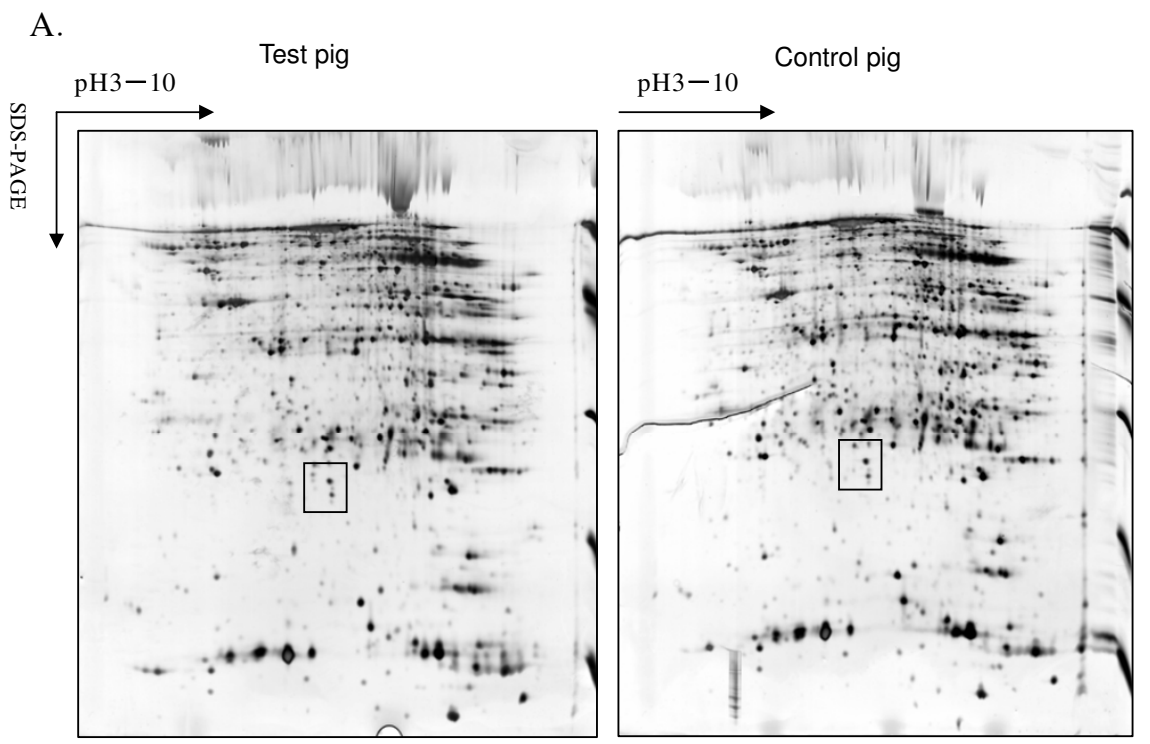

B.

B.

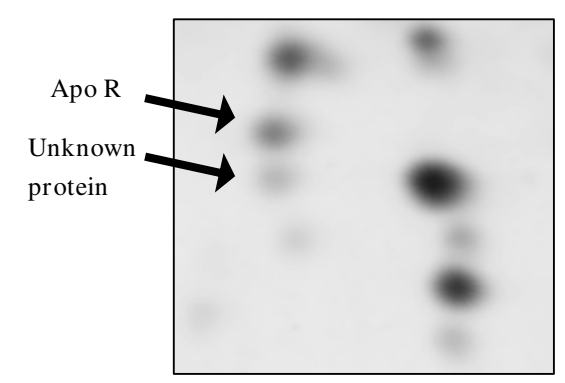

Control pig

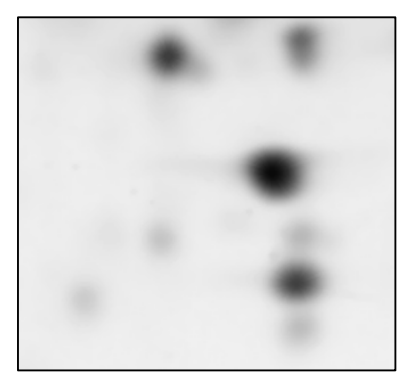

\section{Figure 3}

Proteomic study of adipose tissue of pigs with/without the administration of clenbuterol. A. Two-dimensional gel analysis of total proteins from adipose tissue treated with/without clenbuterol. (I3\% SDS-PAGE, silver stain) $600 \pm 50$ protein spots were detected. B. Two differentially expressed protein spots (Amplified from the frame in A). 
and protein translocation, were enhanced in the adipose cells by clenbuterol stimulation.

\section{cAMP signaling pathway related genes in group II}

The beta-androgenic receptor ( $\beta$-AR) signal pathway has been well described previously [11]. Clenbuterol as a beta-agonist works by binding with $\beta$-AR which then transmits signals into the cell along the $\mathrm{G}$ protein-mediated CAMP signal pathway [29]. However, the molecular level mechanisms by which clenbuterol affects adipose accumulation are still unknown. To examine the expression level of genes related to cAMP or G-protein, a total of 11 genes were found directly related to cAMP or G-protein in the microarray gene list. Only two of the eleven were found to be up-regulated, the cAMP dependent protein kinase type I regulatory gene (PRKAR1A) and RAB30 (Table 3). Up-regulation of PRKAR1A was confirmed by the real-time PCR. No reports have been found concerning functions of PRKAR1A and RBA30 in adipose cells.

\section{Other signal transduction related genes in group II}

Another seven signal transduction genes were found to be differentially expressed (Table 3). Five genes (RACK1, WNT3A, VDAC3, S100A6, THBS4) encoding signal transduction molecules are calcium related. This indicates that clenbuterol may have an impact on calcium signaling pathways in cells. Both RACK1 and WNT3A activate protein kinase $\mathrm{C}$, while protein kinase A has previously been reported as the target of clenbuterol. All this data suggests that clenbuterol's effects on adipose cell may be more complex than previously suggested.

Fibromodulin participates in the assembly of the extracellular matrix as it interacts with type I and type II collagen fibrils [30]. Several collagen genes were also found to be up-regulated (Table 5). This indicates that clenbuterol may have an effect on cell collagen synthesis which may alter the cell matrix composition. It is difficult to determine whether this has any relationship to trigalloyl glycerol accumulation.

\section{ESTs sequence in group IV}

45 differentially expressed ESTs are listed in Table 4. Specific conclusions can not be derived from these ESTs results at this time. Some key genes for lipid metabolism, which are unknown at this time, may be found from this list in the future.

\section{Clenbuterol stimulates genes up-regulated}

Only three genes were found to be down-regulated in the 82 differentially expressed genes. To further investigate whether some genes were down-regulated by the administration of clenbuterol, PHPT1 (phosphohistidine phosphatase 1) and PMP22 (peripheral myelin protein 22) were analyzed by real-time PCR (Table 7). These two genes were down-regulated in the 3 month-old group ( $\mathrm{p}$ $=0.03)$, but they were not statistically differentially expressed in the 4 month-old group $(\mathrm{p}=0.09)$ by the microarray analysis. The PCR results showed that the mRNA expression of these two genes were not changed significantly $(\mathrm{P}>0.05)$ which confirms the unusual microarray result that very few genes were suppressed. This data suggests that clenbuterol stimulates gene up-regulation in adipose cells.

\section{Conclusion}

Pig fat accumulation was reduced dramatically with clenbuterol treatment. Histological sections and global evaluation of gene expression after administration of clenbuterol in pigs identified profound changes in adipose cells. With clenbuterol stimulation, adipose cell volumes decreased and their gene expression profile changed, which indicate some metabolism processes have been also altered. Although the biological functions of the differentially expressed genes are not completely known, higher expressions of these molecules in adipose tissue might contribute to the reduction of fat accumulation. Among these genes, five lipid metabolism related genes were of special interest for further study, including apoD and apoR. The apoR expression was increased at both the RNA and protein levels. The apoR may be one of the critical molecules through which clenbuterol reduces fat accumulation.

\section{Methods}

\section{Animal sampling and clenbuterol treatment}

Eight Chinese miniature pigs were used in the experiments. Four hogs and four sows, all 4 weeks old, were housed in the Nutrition and Metabolism Laboratory at the China Agriculture University. They were raised under exactly the same conditions and were fed the same diets until 8 weeks (average body weight $17 \mathrm{~kg}$ ). They were randomly divided into 4 groups with each group having two pigs with the same gender and the same parents. For the following 4 weeks, one pig in each group was fed $25 \mathrm{mg} /$ $\mathrm{kg}$ clenbuterol twice daily in their diets as the test pig, while the other was fed the same diet without clenbuterol as the control. Then one group of hogs and one group of sows were slaughtered for analysis. These two groups are referred to as the 3 month-old pigs. The other two groups were fed with/without $50 \mathrm{mg} / \mathrm{kg}$ clenbuterol twice daily in their diets for another 4 weeks and slaughtered for analysis. These two groups are referred to as the 4 month-old pigs. Approximately $1 \mathrm{~g}$ biopsies of different tissues, including the back fat adipose tissues (at the fifth lumbar vertebra level), skeleton muscle (biceps femoris and sural muscle), liver, heart, kidney, spleen and lung, were taken from each pig. Samples were washed in sterile water, snap frozen in liquid nitrogen and stored at $-80^{\circ} \mathrm{C}$. 


\section{Histology}

Tissue samples were fixed in 4\% formaldehyde in PBS, embedded in paraffin, and sectioned (5 $\mu \mathrm{m}$ sections). After deparaffinization and rehydration, the sections were washed three times with PBS and stained with H\&E.

\section{RNA preparation, RNA labeling and DNA microarray hybridization}

Total RNA of the adipose tissue was extracted with TRIZOL reagent (Invitrogen, Gaithersburg, MD, USA) and further purified with an RNeasy mini kit (Qiagen, Valencia, CA, USA) according to the manufacturers' instructions.

The porcine cDNA microarray was produced at the China Agricultural University. A total of 11520 spots representing 3358 genes (ESTs) were included on the microarray slide. 3358 genes (ESTs) were cloned from the porcine adipose cDNA library and printed in triplicate on each slide. (More details on the specific genes and probe sequences are given by Guo et al. [31]).

A cDNA microarray hybridization analysis was performed with Pronto! ${ }^{\mathrm{TM}}$ Universal Microarray Kits (Corning, MA, USA) according to the manufacturers instructions. Briefly, reverse transcription was done with $10 \mu \mathrm{g}$ total RNA as the template to synthesize cDNA incorporating the fluorescence dyes Cy3-dCTP or Cy5-dCTP. Probes were purified on a Qiagen spin column (Qiagen, Valencia, CA, USA). Dye-labelled cDNA was mixed together with dry dyelabeled cDNA for hybridization (see Pronto Universal hybridization kit Quick Reference Guide).

To avoid dye bias, the experiments were performed in duplicate by dye swap with Cy5-dCTP first used with the test pig and Cy3-dCTP used with the control pig and then Cy3-dCTP used with the test pig and Cy5-dCTP used with the control pig.

Eight cDNA microarray slides were hybridized for the eight pigs.

\section{DNA microarray Imaging and data analysis}

Arrays were scanned with a ScanArray Express scanner (Parckard Bioscience, Kanata, OT, USA) with the obtained images analyzed with GenePix Pro 4.0 (Axon Instruments, Foster City, CA) and Acuity 4.0 (Axon Instruments, Foster City, CA). The resulting microarray data was then normalized using the space and intensity-dependent normalization in the LOWESS program [32]. Each gene was represented in triplicate on each slide. The intensity (median) of each spot was analyzed using the student ttest to identify the differentially expressed genes $(\mathrm{P}<$ 0.05). Low quality spots were filtered out before the student t-test analysis. Low quality spots refer to stained spots with bad images or spots with intensities (median) lower than 200 (too weak) or greater than 60000 (saturated). Differentially expressed genes were defined as genes with $P$ values less than 0.05 in the eight microarray slides. The mean ratios of the differentially expressed genes (ESTs) were calculated as the "ratio of the median" of three spots to indicate the trends in the changes of the mRNA abundance.

The microarray data from this research has been deposited in the NCBI Gene Expression Omnibus data repository under accession numbers GSE8093 [33].

\section{Quantitative Real-Time PCR}

Fluorescent real-time PCR was used to confirm the transcriptional differences observed in the microarray results, The real-time PCR was done on an ABI Prism 9700 Sequence Detection system (Applied Biosystems, Foster, CA, USA) using SYBRgreen technology as described by Li et al. [34]. The PCR primer sequences used for the realtime PCR are shown in Table 8 . The PCR reaction volume was $20 \mu \mathrm{l}$ with the following program:

$50^{\circ} \mathrm{C} 2 \mathrm{~min}$ (activate the uracil-N-glycosylase enzyme);

$95^{\circ} \mathrm{C} 10 \mathrm{~min}$ (initial denaturation of the cDNA) ;

40 cycles ( $1 \mathrm{sec}$ at various elevated temperatures for data acquisition): $95^{\circ} \mathrm{C} 20 \mathrm{sec}$, annealing (according to the specifications for each primer) $20 \mathrm{sec}, 72^{\circ} \mathrm{C} 20 \mathrm{sec}$;

$72{ }^{\circ} \mathrm{C} 10 \mathrm{~min}$ (reformation of fully duplexed DNA);

The dissolve curve analysis used heating from 65 to $95^{\circ} \mathrm{C}$, with increases of $0.2^{\circ} \mathrm{C}$ per step with the system held $1 \mathrm{sec}$ at each temperature.

All samples were measured in triplicate. Expression was quantified by the relative standard curve method. A standard graph of the cycle threshold (CT) values was obtained from serial dilutions $\left(10^{-1}-10^{-8}\right.$ copies/well) of Glyceraldehyde-3-phosphate dehydrogenase (GAPDH, a housekeeping gene) cDNA. The quantification was normalized to an endogenous RNA control of the GAPDH or beta2microglobulin (B2M). An independent sample t-test was used to analyze differences in mRNA expression with/ without administration of clenbuterol. Differences were considered to be statistically significant at $\mathrm{P}<0.05$. Reactions for which the housekeeping gene's CT values were less than 15 or more than 25 were discarded in the calculations because the start cDNA concentration was not appropriate or the cDNA quality was not good enough. 
Table 8: Primers used for the real-time PCR analysis

\begin{tabular}{|c|c|c|c|}
\hline Genes \& clone number & Primer sequence (5' to $\left.3^{\prime}\right)$ & PCR product size (bp) & Annealing Temperature \\
\hline GAPDH & $\begin{array}{l}\text { For. ATGGTGAAGGTCGGAGTGA Rev. } \\
\text { ATGGGTAGAATCATACTGGA }\end{array}$ & $154 \mathrm{bp}$ & $57^{\circ} \mathrm{C}$ \\
\hline Beta 2-microglobulin (B2M) & $\begin{array}{l}\text { For. TGG TCTTTCTACCTTCTGGCCC Rev. } \\
\text { TGTGATGCCGGTTAGTGGTCTC }\end{array}$ & $166 \mathrm{bp}$ & $60^{\circ} \mathrm{C}$ \\
\hline Apolipoprotein D (rpfat_18926) & $\begin{array}{l}\text { For. AGATCCCAGTGAGCTTTGAG Rev. } \\
\text { CGTAGTTCTCATAGTCGGTG }\end{array}$ & $233 \mathrm{bp}$ & $58^{\circ} \mathrm{C}$ \\
\hline PRKARIA (rpfat_I766I) & $\begin{array}{l}\text { For. GGCGACGAGGTGCTATCAG Rev. } \\
\text { ATGGCATCAAAAATATCAC }\end{array}$ & $159 \mathrm{bp}$ & $60^{\circ} \mathrm{C}$ \\
\hline COLIAI (rpfat_8523) & $\begin{array}{l}\text { For. TCAAGATGTGCCACTCCGACT Rev. } \\
\text { GCCTGTCTCCATGTTGCAGAA }\end{array}$ & 104 bp & $60^{\circ} \mathrm{C}$ \\
\hline COLIA2 (rpfat_I6033) & $\begin{array}{l}\text { For. ATATGCACCTTGGACATCGGT Rev. } \\
\text { CACGATGCTCTGATCAATCCT }\end{array}$ & $241 \mathrm{bp}$ & $60^{\circ} \mathrm{C}$ \\
\hline COL3AI (rpfat_19990) & $\begin{array}{l}\text { For. CCTGCTGGAAAGAATGGTGAC Rev. } \\
\text { ACGTTCACCGGTTTCACCTT }\end{array}$ & $132 \mathrm{bp}$ & $60^{\circ} \mathrm{C}$ \\
\hline COLIA2 (rpfat_I7393) & $\begin{array}{l}\text { For. CCTGGCTCTAGAGGTGAACG Rev. } \\
\text { AGCAGGACCAGGATTACCAG }\end{array}$ & $247 \mathrm{bp}$ & $60^{\circ} \mathrm{C}$ \\
\hline COL3AI (rpfat_l8309) & $\begin{array}{l}\text { For. TTTCTTTTATGGCTCCCCCTG Rev. } \\
\text { GCGTGTTCGATATTCGAAGAC }\end{array}$ & $101 \mathrm{bp}$ & $60^{\circ} \mathrm{C}$ \\
\hline SCD (rpfat_I6685) & $\begin{array}{l}\text { For. AAGGAACTAGAAGGCTGCTC Rev. } \\
\text { TGTAGAGCAGCAGCCATCAC }\end{array}$ & $156 \mathrm{bp}$ & $58^{\circ} \mathrm{C}$ \\
\hline PHPTI (rpfat_I53I2) & $\begin{array}{l}\text { For. GAAGACACAGTTGAGGACAC Rev. } \\
\text { GGACATTGTTCGGAGGATAG }\end{array}$ & $110 \mathrm{bp}$ & $60^{\circ} \mathrm{C}$ \\
\hline HSL (rpfat_II096) & $\begin{array}{l}\text { For. TCCGAATGGAGTCTGCACTGT Rev. } \\
\text { CTTCCACTCTGACCTCCAACG }\end{array}$ & $128 \mathrm{bp}$ & $60^{\circ} \mathrm{C}$ \\
\hline PMP22 (rpfat_I8575) & $\begin{array}{l}\text { For. CATGAACATTTGCACCACTTG Rev. } \\
\text { GTCAGCACCTAATGGTATGGA }\end{array}$ & $133 \mathrm{bp}$ & $60^{\circ} \mathrm{C}$ \\
\hline
\end{tabular}

For.: Forward

Rev.: Reverse

\section{Proteome analysis}

Protein extraction from adipose cells, two-dimensional electrophoresis and in-gel digestion were conducted as described by Lee et al. [35]. After in-gel digestion, samples were dissolved in $4 \mathrm{ml} 0.5 \%$ aqueous trifluoroacetic acid for mass spectrometric analysis on a Bruker REFLEX III MALDI-TOF-MS (Bruker-Franzen, Bremen, Germany) in positive ion mode at an accelerating voltage of $20 \mathrm{kV}$ with an a-cyano-4-hydroxy cinnamic acid matrix. The resulting peptide mass fingerprint (PMF) was then used in a search of the SWISS-PROT and NCBInr databases using the Mascot search engine [20] with a tolerance of $\pm 0.2 \mathrm{D}$ and one missed cleavage site.

\section{Authors' contributions}

Jin Zhang participated in the experimental design, animal feeding and sampling, and the microarray creation and hybridization. Jin Zhang also completed the microarray data analysis, real-time PCR experiments and drafted the manuscript. Qiang He conducted the proteomic research. Qiu Y. Liu helped with the real-time PCR for validation of the microarray data. Wei Guo helped with the animal feeding, sampling, microarray creation and hybridization. Wei W Zhang performed the statistical analyses. Xiao X. $\mathrm{Hu}$, Mei X. Deng and Ning Li designed and oversaw the research and assisted in writing the manuscript. All authors read and approved the final manuscript.

\section{Additional material}

\section{Additional file 1}

Original data of the research. The data include four tables as follow. Table 1. Clenbuterol residue in porcine blood and adipose. Table 2. Body weight of pigs treated with/without clenbuterol. Table 3. Cross-sectional area of muscle fibers of pigs with/without the administration of clenbuterol. Table 4. Number of adipose cells on histological section slides visible through the microscope eyepiece.

Click here for file

[http://www.biomedcentral.com/content/supplementary/14712164-8-433-S1.pdf]

\section{Acknowledgements}

This work was supported by the Natural Scientific Foundation of China, the National Basic Research Development Program (2006CB200 I00) and the National High Technology Research and Development Program of China (2006AAI0ZI37).

\section{References}

I. Plant DR, Kearns CF, McKeever KH, Lynch GS: Therapeutic clenbuterol treatment does not alter $\mathrm{Ca}^{2+}$ sensitivity of permeabilized fast muscle fibres from exercise trained or untrained horses. J Muscle Res Cell Motil 2003, 24:47I-476. 
2. Kuiper HA, Noordam MY, van Dooren-Flipsen MMH, Schilt R, Roos $\mathrm{AH}$ : Illegal use of beta-adrenergic agonists: European Community. J Anim Sci 1998, 76:195-207.

3. Mazzanti G, Daniele C, Boatto G, Manca G, Brambilla G, Loizzo A New $\beta$-adrenergic agonists used illicitly as growth promoters in animal breeding: chemical and pharmacodynamic studies. Toxicology 2003, 187:91-99.

4. Martinez-Navarro JF: Food poisoning related to consumption of illicit $\beta$-agonist in liver. Lancet 1990, 336: I31 I.

5. Pulce C, Lamaison D, Keck G, Bostvironnois C, Nicolas J, Descotes J: Collective human food poisoning by clenbuterol residues in veal liver. Vet Hum Toxicol 1991, 33:480-48I.

6. Shiu TC, Chong WH: A cluster of clenbuterol poisoning associated with pork and pig offal in Hong Kong. Publ Health Epidemiol Bull 200I, I0:14-17.

7. Mitchell GA, Dunnavan G: Illegal use of beta-adrenergic agonists in the United States. IAnim Sci 1998, 76:208-2 I I.

8. Londos C, Honnor RC, Dhillon GS: cAMP-dependent protein kinase and lipolysis in rat adipocytes. III. Multiple modes of insulin regulation of lipolysis and regulation of insulin responses by adenylate cyclase regulators. J Biol Chem 1985, 260: $15139-15145$

9. Egan J, Greenberg AS, Chang MK, Londos C: Control of endogenous phosphorylation of the major cAMP-dependent protein kinase substrate in adipocytes by insulin and betaadrenergic stimulation. I Biol Chem 1990, 265:|8769-I8775.

10. Greenberg AS, Egan JJ, Wek SA, Garty NB, Blanchette-Mackie EJ, Londos C: Perilipin, a major hormonally regulated adipocytespecific phosphoprotein associated with the periphery of lipid storage droplets. J Biol Chem I99 I, 266: I I 34 I- I I346.

II. Zhang J, Hupfeld C], Taylor SS, Olefsky JM, Tsien RY: Insulin disrupts beta-adrenergic signalling to protein kinase $A$ in adipocytes. Nature 2005, 473:569-573.

12. Spurlock DM, McDaneld TG, Mclntyre LM: Changes in skeletal muscle gene expression following clenbuterol administration. BMC Genomics 2006, 7:320.

13. Kussmann M, Affolter M: Proteomic methods in nutrition. Curr Opin Clin Nutr Metab Care 2006, 9:575-583.

14. Baker PK, Dalrymple RH, Ingle DL, Ricks CA: Use of a $\beta 2$-adrenergic agonist to alter muscle and fat deposition in lambs. J Anim Sci 1984, 59: I256-I26I.

15. Choo J, Horan MA, Little RA, Rothwell NJ: Anabolic effects of clenbuterol on skeletal muscle are mediated by $\beta 2$-adrenoceptor activation. Am J Physiol 1992, 262:50-56.

16. Kim YS, Sainz RD: $\beta_{2}$-adrenergic agonist and hypertrophy of skeletal muscles. Life Sci 1992, 50:397-407.

17. Agrawal S, Thakur P, Katoch SS: Beta adrenoceptor agonists, clenbuterol and isoproterenol retard denervation atrophy in rat gastrocnemius muscle: use of 3-methylhistidine as a marker of myofibrillar degeneration. Jpn J Physiol 2003, 53:229-237.

18. EST database of NCBI [http://www.ncbi.nlm.nih.gov/]

19. Peptide mass fingerprint database [http://www.matrix science.com]

20. Rassart E, Bedirian A, Do Carmo S, Guinard O, Sirois J, Terrisse L, Milne R: Apolipoprotein D. Biochim Biophys Acta 2000 | 482( I-2): | 85-98.

21. Cooper ST, Attie AD: Pig Apolipoprotein R, a new member of the short consensus repeat family of proteins. Biochemistry |992, 3 I: | 2328-12336.

22. Kanoh H, Kai M, Wada I: Molecular characterization of the type 2 phosphatidic acid phosphatase. Chem Phys Lipids 1999, 98(I-2): I I9-26

23. Sun L, Gu S, Sun Y, Zheng D, Wu Q, Li X, Dai J, Dai J, Ji C, Xie Y, Mao $Y$ : Cloning and characterization of a novel human phosphatidic acid phosphatase type 2, PAP2d, with two different transcripts PAP2d_vI and PAP2d_v2. Mol Cell Biochem 2005, 272(I-2):91-96.

24. Enoch HG, Catala $A$, Strittmatter $P$ : Mechanism of rat liver microsomal stearyl-CoA desaturase, Studies of the substrate specificity, enzyme-substrate interactions, and the function of lipid. J Biol Chem 1976, 25 I:5095-5 I 03.

25. Muller-Newen G, Stoffel W: Mitochondrial 3-2trans-Enoyl-CoA isomerase. Purification, cloning, expression, and mitochondrial import of the key enzyme of unsaturated fatty acid beta-oxidation. Biol Chem Hoppe Seyler I991, 372(8):6I 3-624.
26. He XY, Zhang G, Blecha F, Yang SY: Identity of heart and liver L3-hydroxyacyl coenzyme A dehydrogenase. Biochim Biophys Acta 1999, 25; I437(2): I 19-123.

27. Lowe M, Kreis TE: In vivo assembly of coatomer, the COP-I coat precursor. J Biol Chem I996, 27 I(48):30725-30730.

28. Domina F, Niutta PP, Naccari C, Pugliese A, Naccari F: Effects of clenbuterol on haemocoagulation process in calves. J Vet Med A Physiol Pathol Clin Med 2005, 52:53-54.

29. Font B, Eichenberger D, Goldschmidt D, Boutillon MM, Hulmes DJ: Structural requirements for fibromodulin binding to collagen and the control of type I collagen fibrillogenesis - critical roles for disulphide bonding and the C-terminal region. Eur J Biochem 1998, 254(3):580-7.

30. Guo W, Wang HS, Cao HJ, Xu K, Zhang J, Du ZL, Lu W, Feng JD, Li $\mathrm{N}, \mathrm{Wu} \mathrm{CH}$, Zhang L: Gene Microarray Analysis for Porcine Adipose Tissue: Comparison of Gene Expression between Chinese Xiang Pig and Large White. Asian-Aust J Anim Sci in press.

31. Yang YH, Dudoit S, Luu P, Lin DM, Peng V, Ngai J, Speed TP: Normalization for cDNA microarray data: a robust composite method addressing single and multiple slide systematic variation. Nucleic Acids Res 2002, 30(4):el 5.

32. The microarray database [http://www.ncbi.nlm.nih.gov/geo/]

33. Li S, Li Y, Du W, Zhang L, Yu S, Dai Y, Zhao C, Ning Li: Aberrant Gene Expression in Organs of Bovine Clones That Die Within Two Days after Birth. Biol Reprod 2005, 72:258-265.

34. Lee HK, Lee BH, Park SA, Kim CW: The proteomic analysis of an adipocyte differentiated from human mesenchymal stem cells using two-dimensional gel electrophoresis. Proteomics 2006, 6:1223-1229.

Publish with BioMed Central and every scientist can read your work free of charge

"BioMed Central will be the most significant development for disseminating the results of biomedical research in our lifetime. "

Sir Paul Nurse, Cancer Research UK

Your research papers will be:

- available free of charge to the entire biomedical community

- peer reviewed and published immediately upon acceptance

- cited in PubMed and archived on PubMed Central

- yours - you keep the copyright
BioMedcentral 